\title{
Inheritance and relationships of flowering time and seed size in kabuli chickpea
}

\author{
Prity Sundaram - Srinivasan Samineni - Sobhan B. Sajja • Chandan Roy • \\ Suresh P. Singh · Priyanka Joshi • Pooran M. Gaur (i)
}

Received: 15 March 2019/ Accepted: 13 July 2019

(C) Springer Nature B.V. 2019

\begin{abstract}
Flowering time and seed size are the important traits for adaptation in chickpea. Early phenology (time of flowering, podding and maturity) enhance chickpea adaptation to short season environments. Along with a trait of consumer preference, seed size has also been considered as an important factor for subsequent plant growth parameters including germination, seedling vigour and seedling mass. Small seeded kabuli genotype ICC 16644 was crossed with four genotypes (JGK 2, KAK 2, KRIPA and ICC 17109) to study inheritance of flowering time and seed size. The relationships of phenology with seed size, grain yield and its component traits were studied. The study included parents, $F_{1}, F_{2}$ and $F_{3}$ of four crosses. The segregation data of $F_{2}$ indicated flowering time in chickpea was governed by two genes with duplicate recessive epistasis and lateness was dominant to earliness. Two genes were controlling 100-seed weight where small seed size was dominant over
\end{abstract}

P. Sundaram - S. Samineni - S. B. Sajja ·

P. Joshi · P. M. Gaur ( $\bowtie)$

International Crops Research Institute for the Semi-Arid

Tropics (ICRISAT), Hyderabad 502 324, India

e-mail: p.gaur@cgiar.org

P. Sundaram - C. Roy · S. P. Singh

Bihar Agricultural University,

Sabour, Bhagalpur 813 210, India

P. M. Gaur

The UWA Institute of Agriculture, University of Western Australia, Perth, WA 6009, Australia large seed size. Early phenology had significant negative or no association (ICC $16644 \times$ ICC 17109 ) with 100 -seed weight. Yield per plant had significant positive association with number of seeds per plant, number of pods per plant, biological yield per plant, 100-seed weight, harvest index and plant height and hence could be considered as factors for seed yield improvement. Phenology had no correlation with yield per se (seed yield per plant) in any of the crosses studied. Thus, present study shows that in certain genetic background it might be possible to breed early flowering genotypes with large seed size in chickpea and selection of early flowering genotypes may not essentially have a yield penalty.

Keywords Adaptation - Cicer arietinum . Correlation · Genetics · Market trait · Phenology

\section{Introduction}

Globally chickpea (Cicer arietinum L.) is the third most important food legume crop in the world after beans (Phaseolus vulgaris L.) and pea (Pisum sativum L.) in terms of annual production (FAOSTAT 2017). It is grown over an area of 14.56 million hectares with a production of 14.77 million tonnes and productivity of $1014 \mathrm{~kg}$ per hectare. India is the largest chickpea producing country in the world with a share of $61.4 \%$ 
(9.07 million tonnes) in production and 65.5\% (9.53 million hectares) in area (FAOSTAT 2017). During the past decade, chickpea production increased considerably in Russian Federation, Australia, Tanzania, Ethiopia, United States, Myanmar and India (Gaur et al. 2018). Due to its nutritive seed, which is high in protein content, its use as substitute for animal protein is increasing which is leading to expansion of chickpea area in the world. Along with the yield, phenology (time of flowering, podding and maturity) and seed size are the two important traits in chickpea which decide the choice of farmers' preferences to chickpea variety. Large genotypic variations exist for flowering time in chickpea. Phenology plays critical role in adaptation of chickpea to different environments (Berger and Turner 2004; Berger et al. 2006; Gaur et al. 2008a, b) particularly in semi-arid regions where growth is restricted by water availability and by seasonal temperature profile (Bonfil and Pinthus 1995; Subbarao et al. 1995). Chickpea often experiences short growing season because of terminal stresses (drought, extremes temperatures) which often restrict its yield potential (Khanna-Chopra and Sinha 1987). Early maturity is an important trait for increasing and stabilizing chickpea productivity by avoiding end of season drought (Subbarao et al. 1995; Kumar and Abbo 2001). Early flowering leads to prolong reproductive phase thereby increasing the yield through more efficient water use system (Kumar and Abbo 2001). Early flowering is important in temperate environments for escaping end-of-season frost (Warkentin et al. 2003; Gaur et al. 2015) In chickpea, time of flowering is variable depending upon season, date of sowing, latitude and altitude (Summerfield and Roberts 1988), it is a function of temperature and photoperiod (Roberts et al. 1985; Ellis et al. 1994) or solely photoperiod (Ellis et al. 1994). Studies suggest that flowering time is governed by one or few major genes (Gumber and Singh1996; Or et al. 1999; Kumar and van Rheenen 2000; Anbessa et al. 2006; Hegde 2010; Gaur et al. 2015). In chickpea, four flowering genes have been identified, efl-1 (Kumar and van Rheenen 2000), efl-2 (Or et al. 1999), efl-3 (Hegde 2010), and efl-4 (Gaur et al. 2015). Early flowering genes can be introduced into promising cultivars of late flowering genetic backgrounds. However, breeding programmes with a goal of developing varieties with early phenology, other traits must also be considered. Within cultivated chickpea, two distinct groups of cultivars are found; desi type (pink flowers, angular shaped and brown coloured small seeds) and kabuli type (white flowers, owl's head shaped and beige coloured large seeds). Large-seeded kabuli types are gaining importance as the market price of kabuli chickpea is up to twice that of desi chickpea (Upadhyaya et al. 2006). In kabuli chickpea seed size is an important trait. A wide range of genetic variability is present for seed size in chickpea. Larger seed size coupled with other desirable seed traits (e.g. light colour) commands price premiums in a marketdependant manner (Graham et al. 2001). It is an important component of yield and adaptation (Singh and Paroda 1986). It has also been considered as an important factor for subsequent plant growth parameters including germination, seedling vigour and seedling mass (Narayanan et al. 1981; Dahiya et al. 1985). Earlier studies have reported monogenic (Argikar 1956), digenic (Ghatge 1993; Upadhyaya et al. 2006; Hossain et al. 2010), oligogenic (Patil and D'Cruze 1964) and polygenic (Niknejad et al. 1971; Kumar and Singh 1995; Malhotra et al. 1997; Kumhar et al. 2013) inheritance of seed size depending on the number of genes segregating in the populations studied. According to Smithson et al. (1985) and Kumar and Singh (1995), small seed size was dominant over large one. In contrast, Niknejad et al. (1971) stated that large seed size was partially dominant over the small seed size. The study of inheritance of seed size and flowering time is important for adopting appropriate breeding strategy for developing improved cultivar of chickpea. In framework of an effort to breed early flowering genotypes with large seeds the present investigation was carried out to determine inheritance of flowering time and seed size and whether the phenology affects seed size. In addition, the relationships of phenology with grain yield and its component traits were studied.

\section{Materials and methods}

Five genotypes of chickpea, which included two landraces (ICC 16644 and ICC 17109) and three cultivars (KAK 2, KRIPA and JGK 2) were used as parents for four crosses in the study. All the genotypes were kabuli type. The descriptions of parental lines are given in Table 1 . To study the genetics and segregation patterns of seed size and flowering time, parents 
Table 1 Origin, pedigree and key traits of the parental genotypes

\begin{tabular}{|c|c|c|}
\hline Genotype & Origin/pedigree & Key traits \\
\hline $\begin{array}{l}\text { ICC } \\
16644\end{array}$ & A land race from Punjab province of Pakistan & $\begin{array}{l}\text { Kabuli type, semi-spreading growth } \\
\text { habit, super early and small seed } \\
\text { size }\end{array}$ \\
\hline JGK 2 & $(\mathrm{ICC} 12339 \times \mathrm{ICC} 4967) \times[\{(\mathrm{ICC} 982 \times \mathrm{ICC} 4973) \times \mathrm{ICC} 15980\} \times \mathrm{ICC} 12975]$ & $\begin{array}{l}\text { Kabuli type, semi-spreading growth } \\
\text { habit, medium duration and } \\
\text { medium seed size }\end{array}$ \\
\hline KAK 2 & $(\mathrm{ICCV} 2 \times$ Surutato 77$) \times$ ICC 7344 & $\begin{array}{l}\text { Kabuli type, semi-spreading growth } \\
\text { habit, medium duration and } \\
\text { medium seed size }\end{array}$ \\
\hline KRIPA & Also called Phule G 0517 , a selection from local germplasm & $\begin{array}{l}\text { Kabuli type, semi-spreading growth } \\
\text { habit, medium duration and large } \\
\text { seed size }\end{array}$ \\
\hline $\begin{array}{l}\text { ICC } \\
17109\end{array}$ & A line from Mexico & $\begin{array}{l}\text { Kabuli type, semi-spreading growth } \\
\text { habit, late and large seed size }\end{array}$ \\
\hline
\end{tabular}

differing in both the traits were selected for crossing. ICC 16644 was an early maturing line (early flowering) with small seed size. The remaining genotypes had medium maturity and large (JGK 2 and KAK 2) to extra-large (ICC 17109 and KRIPA) seed size. Four crosses were made by crossing early flowering and small seeded genotype 16644 with the remaining four genotypes KAK 2, JGK 2, KRIPA and ICC 17109. The crosses ICC $16644 \times$ JGK 2, ICC $16644 \times$ KAK 2 , ICC $16644 \times$ KRIPA and ICC $16644 \times$ ICC 17109 were designated as $\mathrm{C}_{1}, \mathrm{C}_{2}, \mathrm{C}_{3}$ and $\mathrm{C}_{4}$ respectively. The $\mathrm{F}_{1}, \mathrm{~F}_{2}$ and $\mathrm{F}_{3}$ along with the respective parents of each cross were sown in the field in November, 2013 (postrainy season) at International Crops Research Institute for the Semi-Arid Tropics (ICRISAT) Patancheru, India $\left(17^{\circ} 52^{\prime} \mathrm{N} 78^{\circ} 24^{\prime} \mathrm{E}\right)$. Seeds were treated before sowing with a mixture of $2 \mathrm{~g}$ thiram and $1 \mathrm{~g}$ of carbendazim per $\mathrm{kg}$ of seed. The seeds were sown at a wider spacing of $60 \mathrm{~cm} \times 20 \mathrm{~cm}$ with single seed per hill in the rows of $4 \mathrm{~m}$. Care was taken to sow the seeds at uniform depth $(5 \mathrm{~cm})$. The plots of various generations contained different number of rows i.e., two rows of parents, one row of $F_{1}$, and six rows each of $F_{2}$ and $\mathrm{F}_{3}$. All recommended agronomical practices (Gaur et al. 2010) and necessary plant protection measures were followed to raise a healthy crop. The minimum and maximum temperature ranged between 8.31-18.34 ${ }^{\circ} \mathrm{C}$ and $26.54-32.22{ }^{\circ} \mathrm{C}$ respectively during the experimental period. One intercultural operation was done to control the weeds and three sprays of Indoxacarb (@20 mL/ha in 300 Lwater)were done to manage pod borer (Helicoverpa armigera). Observations were recorded on individual plants ( 20 plants in parents and $F_{1}, 210$ plants each in $F_{2}$ and $F_{3}$ per cross) for days to first flower, days to first pod formation, days to maturity, plant height $(\mathrm{cm})$, number of pods per plant, number of seeds per plant, number of seeds per pod, grain yield per plant $(\mathrm{g})$, biological yield per plant (g) and 100-seed weight (g). The day first flower fully opened was recorded as days to first flower. The weight of 100 randomly selected seeds from each plant was recorded as 100-seed weight. For those plants which had less than 100-seeds, the weight of 100-seed in grams was calculated by the following formula:

100-seed weight $($ HSW $)=$

$\frac{\text { Weight of total seed of the plant }(\mathrm{g})}{\text { Total number of seeds of the plant }} \times 100$

Data were subjected to mean, variance, range and standard error estimation. Based on distribution pattern in $F_{2}$ and $F_{3}$ population, the quantitative data of days to first flower and 100-seed weight collected from individual plants were converted into qualitative data using different class intervals. The qualitative data was analyzed using $\chi^{2}$ test for Mendelian ratio. In addition, standard statistical procedure, $t$ test, regression and simple correlations were used to analyze the data using GENSTAT (version 18.0). 
Table 2 Days to first flower, maturity and 100-seed weight of parents, $F_{1}, F_{2}$, and $F_{3}$ of four crosses in chickpea

\begin{tabular}{|c|c|c|c|c|c|c|c|}
\hline \multirow[t]{2}{*}{ S. no. } & \multirow[t]{2}{*}{ Parent/generation } & \multicolumn{2}{|c|}{ Days to first flower } & \multicolumn{2}{|c|}{ Days to maturity } & \multicolumn{2}{|c|}{ 100-seed weight $(\mathrm{g})$} \\
\hline & & Mean $\pm \mathrm{SE}$ & Range & Mean $\pm \mathrm{SE}$ & Range & Mean $\pm \mathrm{SE}$ & Range \\
\hline 1 & ICC 16644 & $28.0 \pm 0.17$ & $27-30$ & $80.5 \pm 0.12$ & $80-82$ & $24.6 \pm 0.07$ & $22.9-24.8$ \\
\hline 2 & JGK 2 & $36.7 \pm 0.17$ & $34-38$ & $87.5 \pm 0.16$ & $85-88$ & $36.8 \pm 0.58$ & $32.5-35.8$ \\
\hline 3 & KAK 2 & $35.8 \pm 0.13$ & $35-39$ & $87.5 \pm 0.14$ & $86-89$ & $42.5 \pm 0.54$ & $39.5-43.4$ \\
\hline 4 & KRIPA & $40.8 \pm 0.16$ & $37-41$ & $91.2 \pm 0.12$ & $88-95$ & $51.8 \pm 1.98$ & $49.5-53.1$ \\
\hline 5 & ICC 17109 & $40.2 \pm 0.14$ & $38-42$ & $93.5 \pm 0.17$ & 89-94 & $60.6 \pm 1.17$ & $57.8-62.0$ \\
\hline 6 & $\mathrm{~F}_{1}(\mathrm{ICC} 16644 \times \mathrm{JGK} 2)$ & $48.5 \pm 0.26$ & $48-51$ & $92.4 \pm 0.26$ & $90-95$ & $25.3 \pm 0.70$ & $23.7-25.9$ \\
\hline 7 & $\mathrm{~F}_{1}(\mathrm{ICC} 16644 \times \mathrm{KAK} 2)$ & $49.4 \pm 0.25$ & $49-54$ & $91.8 \pm 0.25$ & $90-96$ & $28.6 \pm 0.59$ & $26.6-28.7$ \\
\hline 8 & $\mathrm{~F}_{1}(\mathrm{ICC} 16644 \times \mathrm{KRIPA})$ & $51.1 \pm 0.24$ & $50-54$ & $94.6 \pm 0.63$ & $92-100$ & $33.2 \pm 0.96$ & $32.7-34.0$ \\
\hline 9 & $\mathrm{~F}_{1}(\mathrm{ICC} 16644 \times \mathrm{ICC} 17109)$ & $51.4 \pm 0.14$ & $51-54$ & $96.6 \pm 0.38$ & 94-101 & $33.7 \pm 0.81$ & $32.3-35.6$ \\
\hline 10 & $\mathrm{~F}_{2}(\mathrm{ICC} 16644 \times \mathrm{JGK} 2)$ & $40.1 \pm 0.63$ & $27-58$ & $87.1 \pm 0.63$ & $78-111$ & $26.4 \pm 0.69$ & $18.3-51.7$ \\
\hline 11 & $\mathrm{~F}_{2}(\mathrm{ICC} 16644 \times \mathrm{KAK} 2)$ & $47.3 \pm 0.76$ & $27-64$ & $93.2 \pm 0.74$ & $78-110$ & $30.3 \pm 0.94$ & $15.8-57.7$ \\
\hline 12 & $\mathrm{~F}_{2}(\mathrm{ICC} 16644 \times \mathrm{KRIPA})$ & $42.3 \pm 0.53$ & $27-63$ & $90.2 \pm 0.53$ & $77-110$ & $36.6 \pm 0.88$ & $14.5-54.8$ \\
\hline 13 & $\mathrm{~F}_{2}(\mathrm{ICC} 16644 \times \mathrm{ICC} 17109)$ & $42.5 \pm 0.71$ & $27-62$ & $91.2 \pm 0.76$ & $76-112$ & $35.8 \pm 0.79$ & $21.9-61.9$ \\
\hline 14 & $\mathrm{~F}_{3}(\mathrm{ICC} 16644 \times \mathrm{JGK} 2)$ & $43.4 \pm 0.56$ & $29-61$ & $87.1 \pm 0.12$ & $78-110$ & $30.8 \pm 0.50$ & $11.7-63.7$ \\
\hline 13 & $\mathrm{~F}_{3}(\mathrm{ICC} 16644 \times \mathrm{KAK} 2)$ & $47.6 \pm 0.73$ & $28-75$ & $93.3 \pm 0.26$ & 79-107 & $28.7 \pm 0.45$ & $14.3-54.2$ \\
\hline 16 & $\mathrm{~F}_{3}(\mathrm{ICC} 16644 \times \mathrm{KRIPA})$ & $45.5 \pm 0.79$ & $28-73$ & $94.6 \pm 0.61$ & $78-111$ & $34.3 \pm 0.48$ & $18.3-55.9$ \\
\hline 17 & $\mathrm{~F}_{3}(\mathrm{ICC} 16644 \times \mathrm{ICC} 17109)$ & $46.0 \pm 0.63$ & $29-71$ & $95.4 \pm 0.36$ & $79-111$ & $35.5 \pm 0.54$ & $21.3-62.9$ \\
\hline
\end{tabular}

\section{Results and discussion}

Inheritance of flowering time

The flowering time of parental lines varied from 27 to 42 days (Table 2). The $\mathrm{F}_{1} \mathrm{~s}$ of all the crosses were late to flower with mean flowering time of 48.5, 49.4, 51.1 and 51.4 days in $\mathrm{C}_{1}, \mathrm{C}_{2}, \mathrm{C}_{3}$ and $\mathrm{C}_{4}$ respectively, indicating dominance of lateness in all the four crosses. In chickpea, late flowering is known to be dominant over early flowering (Gumber and Singh 1996; Or et al. 1999; Kumar and van Rheenen 2000; Anbessa et al. 2006; Hegde 2010; Gaur et al. 2015). $F_{2}$ and $\mathrm{F}_{3}$ populations of all crosses had wide variation for flowering time. The frequency distributions of flowering timing in $\mathrm{F}_{2}$ of each cross was skewed towards late parent and also number of plants with late flowering was much higher than the number of plants with early flowering, indicating late flowering is dominant over early flowering. $\mathrm{F}_{2}$ segregation for days to first flower in $\mathrm{C}_{1}, \mathrm{C}_{2}, \mathrm{C}_{3}$ and $\mathrm{C}_{4}$ had a range of 27-58 days, 27-64 days, 27-63 days, and 27-62 days respectively. All $\mathrm{F}_{2}$ populations had transgressive segregants in both directions for flowering time. The individuals were grown during post-rainy season and they flowered during the period when temperatures were not very high $\left[28.1{ }^{\circ} \mathrm{C}\right.$ (average maximum temperature) and $13.1{ }^{\circ} \mathrm{C}$ average minimum temperature)] and days were long with mean bright sunshine hours of 9.7 (28-36 days after sowing), 8.1 (36-56 days after sowing) and 7.0 (57-70 days after sowing). Physiological study revealed that flowering time is a function of temperature and photoperiod in chickpea (Roberts et al. 1985). Three factors, response to photoperiod, response to temperature and "earliness per se genes" have been reported to determine time of flowering in wheat (Snape et al. 2001). Transgressive segregation in the study may be the results of new genetic combinations related to photo-thermal response and earliness per se genes.

The quantitative data for flowering time in each $\mathrm{F}_{2}$ was converted to qualitative data and individuals were classified into two groups i.e. early and late flowering depending upon natural break points in the distribution frequency within each population (Fig. 1). Classification of $\mathrm{F}_{2}$ individual into groups varied among crosses, it may be due to individual effect of genes present in the parent selected for the crosses. The $F_{2}$ populations 


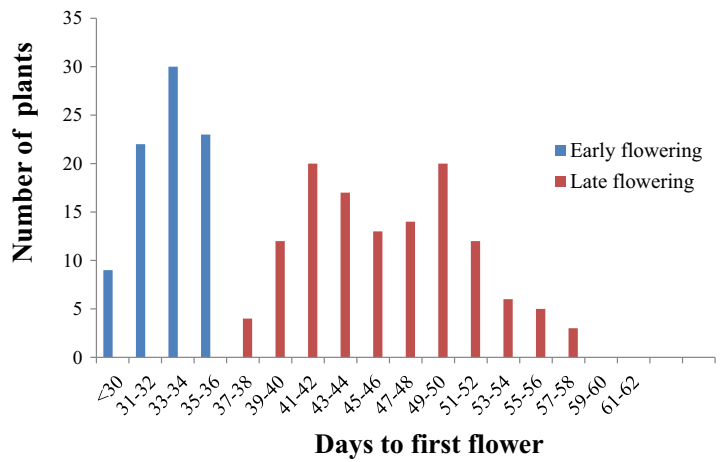

(a)

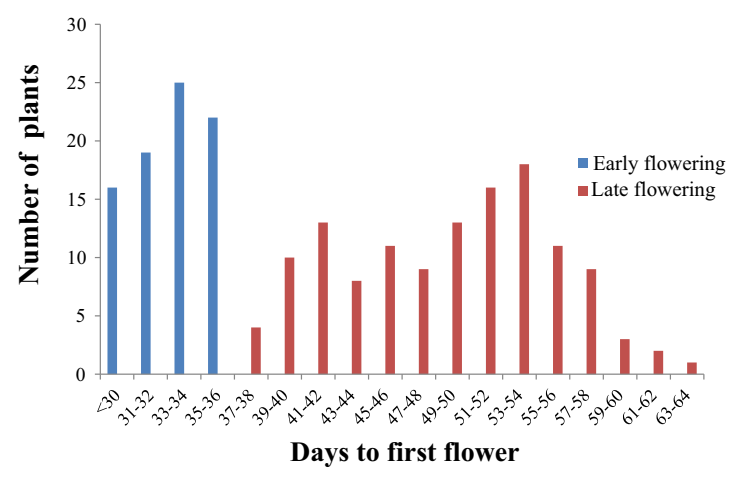

(c)

Fig. 1 a Distribution of flowering time in $\mathrm{F}_{2}$ populations of the cross ICC $16644 \times$ JGK 2 . b Distribution of flowering time in $\mathrm{F}_{2}$ populations of the cross ICC $16644 \times$ KAK 2. c Distribution

of all the crosses gave good fit to a ratio of late to early flowering of 9:7 with non-significant $\chi^{2}$ values (Table 3). This indicates that the flowering time was governed primarily by two genes with duplicate recessive epistasis between them. In chickpea, Anbessa et al. (2006) and Gaur et al. (2015) reported two major genes with duplicate recessive epistasis controlling flowering time. In a different study using $\mathrm{F}_{2}$ population, it was reported that flowering time in chickpea was governed by duplicate dominant genes (good fit to a 9:6:1 ratio) with cumulative but unequal effect (Hegde 2010). Segregation pattern may differ in different studies depending upon variable effects of major and minor genes present for the flowering time and the classification of individuals in different classes. Genes responsible for flowering time are identified in many legumes. One gene in each was reported in common bean (Coyne and Mattson 1964)

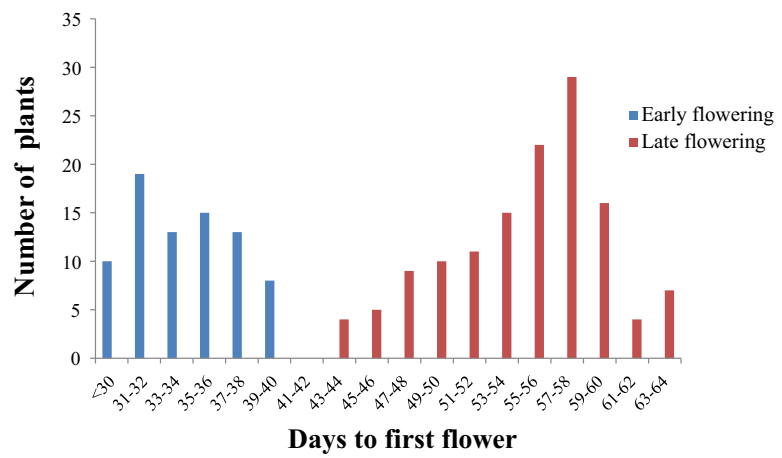

(b)

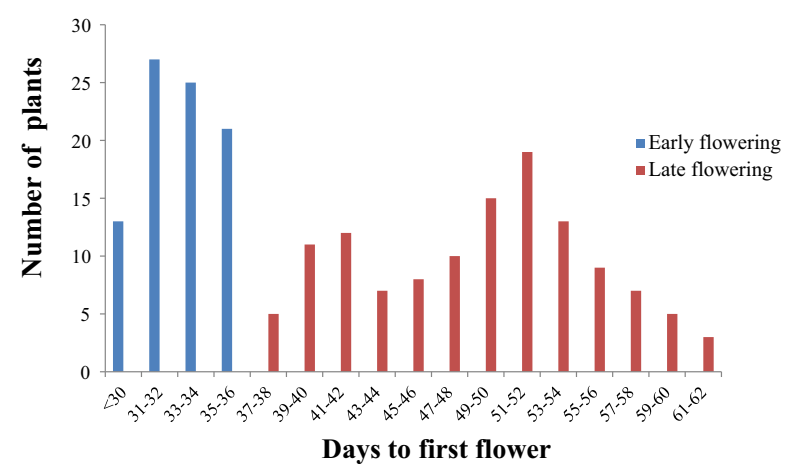

(d)

of flowering time in $\mathrm{F}_{2}$ populations of the cross ICC $16644 \times$ KRIPA. d Distribution of flowering time in $F_{2}$ populations of the cross ICC $16644 \times$ ICC 17109

and lentil (Sarker et al. 1999), two in pigeon pea (Koebner et al. 1991; Craufurd et al. 2001), six in pea (Murfet 1985 and eight in soybean (Bernard 1971; Buzzell 1971; Buzzell and Voldeng 1980; McBlain and Bernard 1987; Ray et al. 1995; Bonato and Vello 1999; Cober and Voldeng 2001). Late flowering was dominant to early flowering in all the above studies except for pigeon pea (Saxena and Sharma 1990) and common bean (Coyne and Mattson 1964) where earliness was dominant to lateness. The genetic basis of flowering time genes observed in the present study reveals that early-flowering trait in chickpea can be easily incorporated into high-yielding cultivars by backcross breeding or by selection of desired type individual in $\mathrm{F}_{2}$ and subsequent generations. 
Table 3 Goodness-of-fit ( $\chi^{2}$-test) for a 9:7 ratio for late and early flowering; and small and large seed size plants observed in $\mathrm{F}_{2}$ of four crosses in chickpea

\begin{tabular}{|c|c|c|c|c|c|c|}
\hline \multirow[t]{2}{*}{ S. no. } & \multirow{2}{*}{$\begin{array}{l}\text { Trait/cross } \\
\text { Flowering time }\end{array}$} & \multicolumn{2}{|c|}{$\mathrm{F}_{2}$ observed phenotype } & \multirow[t]{2}{*}{ Expected ratio } & \multirow[t]{2}{*}{$\chi^{2}(\mathrm{~ns})$} & \multirow[t]{2}{*}{$P$-value } \\
\hline & & Late flowering & Early flowering & & & \\
\hline 1 & ICC $16644 \times$ JGK 2 & 126 & 84 & $9: 7$ & 1.19 & 0.27 \\
\hline 2 & ICC $16644 \times$ KAK 2 & 132 & 78 & $9: 7$ & 3.71 & 0.06 \\
\hline 3 & ICC $16644 \times$ KRIPA & 128 & 82 & $9: 7$ & 1.87 & 0.18 \\
\hline \multirow[t]{2}{*}{4} & ICC $16644 \times$ ICC 17109 & 124 & 86 & $9: 7$ & 0.66 & 0.42 \\
\hline & Seed size & Small seeded & Large seeded & & & \\
\hline 5 & ICC $16644 \times$ JGK 2 & 116 & 94 & $9: 7$ & 0.09 & 0.76 \\
\hline 6 & ICC $16644 \times$ KAK 2 & 120 & 90 & $9: 7$ & 0.06 & 0.79 \\
\hline 7 & ICC $16644 \times$ KRIPA & 125 & 85 & $9: 7$ & 0.91 & 0.34 \\
\hline 8 & ICC $16644 \times$ ICC 17109 & 118 & 92 & $9: 7$ & 0.01 & 0.98 \\
\hline
\end{tabular}

$n s$ non-significant, $P$-value probability value

Inheritance of seed size

100-seed weight of JGK 2, KAK 2, KRIPA and ICC 17109 were on average $49.8 \%, 72.8 \%, 110.5 \%$ and $136.6 \%$ heavier than that of the small seeded parent (ICC 16644). The 100-seed weight of ICC 16644 was $24.6 \mathrm{~g}$ with a range of $22.9-24.8 \mathrm{~g}$. The 100 -seed weight of $\mathrm{F}_{1} \mathrm{~s}$ were $25.3 \mathrm{~g}, 28.6 \mathrm{~g}, 33.2 \mathrm{~g}$ and $33.7 \mathrm{~g}$ in $\mathrm{C}_{1}, \mathrm{C}_{2}, \mathrm{C}_{3}$ and $\mathrm{C}_{4}$ respectively. The 100 -seed weight of $\mathrm{F}_{1} \mathrm{~s}$ was lower than that of the mid parental value in all the crosses indicating, small seed size is dominant over large seed size. Majority of previous studies indicated dominance of small seed size over large seed size (Smithson et al. 1985; Kumar and Singh 1995; Malhotra et al. 1997; Upadhyaya et al. 2006; Hossain et al. 2010; Upadhyaya et al. 2011) except Niknejad et al. (1971) who stated that large seed size was partially dominant over small seed size. Seed size in legume crops is generally attributed to the cell number and cell size of cotyledons (Lemontey et al. 2000). The range and variation in 100-seed weight in segregating generations $\left(\mathrm{F}_{2}\right.$ and $\left.\mathrm{F}_{3}\right)$ were high in all the crosses. The mean 100-seed weight of parents, $F_{1}, F_{2}$ and $F_{3}$ are given in Table 2. Despite of continuous variation exhibited by seed size of $F_{2}$ in all crosses, frequency distribution of seed size displayed definite segregating patterns. The quantitative data on 100 -seed weight were converted into two different phenotypic classes (small seeded and large seeded) based on natural break points in the distribution frequency. For example, in frequency distribution of 100-seed weight of individual plants of $F_{2}$ in $C_{1}$, two peaks at $29 \mathrm{~g}$ and $39 \mathrm{~g}$ and valley (break point) at $35 \mathrm{~g}$ were observed (Fig. 2). So, the individual plants with 100-seed weight up to $35 \mathrm{~g}$ were grouped into small seeded and those having 100-seed weight more than $35 \mathrm{~g}$ were grouped into large seeded. Similarly, natural breakpoints of 100-seed weight were observed at $31 \mathrm{~g}$ $\left(\mathrm{C}_{2}\right)$ and $39 \mathrm{~g}\left(\mathrm{C}_{3}\right.$ and $\left.\mathrm{C}_{4}\right)$ and $\mathrm{F}_{2}$ individuals of each cross were divided into two groups. All the four crosses exhibited skewness of data on 100-seed weight towards smaller seed weight. The numbers of individuals with small seed size and large seed size in $\mathrm{F}_{2}$ populations of each cross fitted well to the expected ratio of 9:7 suggesting 100-seed weight in all crosses were governed by two genes with complementary gene action (Table 3). These results were consistent with di-genic inheritance with duplicate recessive epistasis. In a previous study of a cross between two kabuli chickpea the number of plants in the three groups in $\mathrm{F}_{2}$ fitted well to an expected ratio of 5:6:5 and in backcross generations to an expected ratio 1:2:1 which suggested that seed size in the two parents is controlled by two genes exhibiting additive effects with each parent having one pair of alleles with increasing effect at one locus in homozygous form (Upadhyaya et al. 2011). The $F_{2}$ plants of different study fitted well to the expected ratio of 12:3:1 (Upadhyaya et al. 2006) suggesting that seed size in chickpea is controlled by two genes exhibiting dominance epistasis with dominance of normal seed size over small seed size. Di-genic mode of inheritance for 


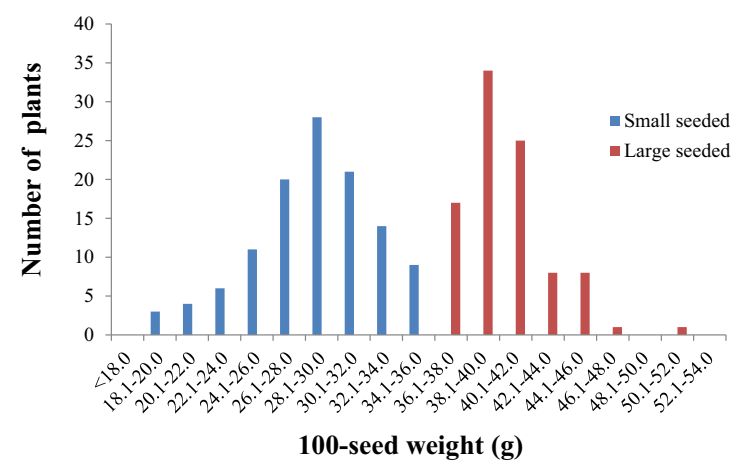

(a)

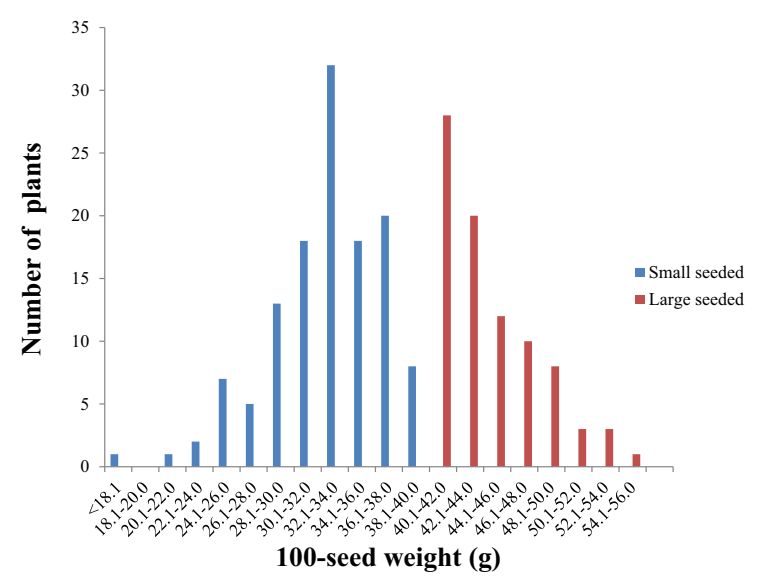

(c)

Fig. 2 a Distribution of 100 -seed weight in $\mathrm{F}_{2}$ populations of the cross ICC $16644 \times$ JGK 2. b Distribution of 100-seed weight in $F_{2}$ populations of the cross ICC $16644 \times$ KAK 2 .

seed size in chickpea has been reported earlier (Ghatge 1993; Upadhyaya et al. 2006; Hossain et al. 2010). In some studies, it was considered monogenic (Argikar 1956), oligogenic (Balasubrahmanyan 1950; Patil and D'Cruze 1964) and polygenic (Niknejad et al. 1971; Kumar and Singh 1995; Malhotra et al. 1997; Kumhar et al. 2013) depending on the number of genes segregating in the populations.

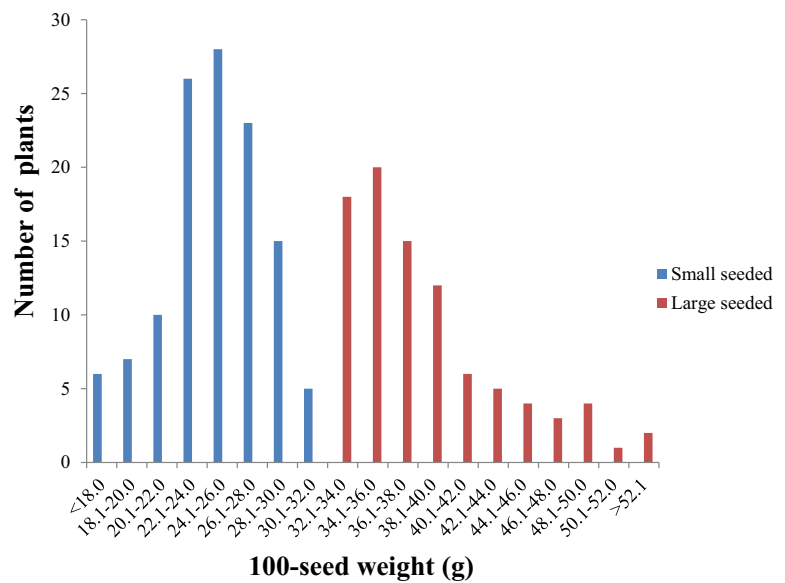

(b)

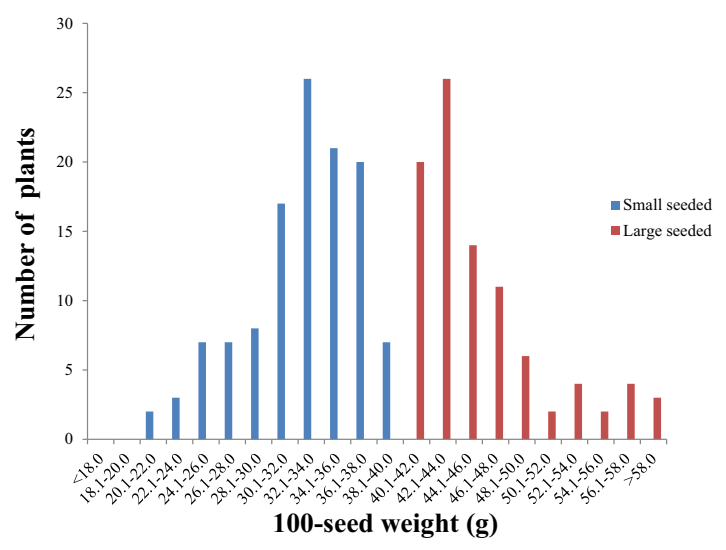

(d)

c Distribution of 100-seed weight in $\mathrm{F}_{2}$ populations of the cross ICC $16644 \times$ KRIPA. d Distribution of 100 -seed weight in $\mathrm{F}_{2}$ populations of the cross ICC $16644 \times$ ICC 17109

Comparisons of means of different groups based on days to flowering and 100-seed weight

The mean of 100-seed weight of two groups i.e. early flowering and late flowering were compared with each other in each cross using $t$-test to find out whether the flowering individuals had more 100-seed weight and vice versa (Table 4). Significant differences for 100-seed weight were observed between early flowering group and late flowering group in $\mathrm{C}_{1}(t$ value: 4.08, $P<0.001)$ and $\mathrm{C}_{2}(t$ value $4.51, P<0.001)$ indicating early flowering individuals could assimilate more photosynthates as compared to late flowering 
Table 4 Differences in mean seed size (100-seed weight) between early and late flowering groups of $F_{2}$ plants and differences between mean days to first flower between small-seeded and large-seeded groups of $F_{2}$ plants

\begin{tabular}{|c|c|c|c|c|c|c|}
\hline Cross & $\begin{array}{l}\text { No. of } \\
\text { plants }\end{array}$ & $\begin{array}{l}\text { 100-seed weight (mean } \pm \text { SE) of } \\
\text { early flowering plants of } F_{2}\end{array}$ & $\begin{array}{l}\text { No. of } \\
\text { plants }\end{array}$ & $\begin{array}{l}\text { 100-seed weight (mean } \pm S E \text { ) of } \\
\text { late flowering plants of } F_{2}\end{array}$ & $t$-test & $P$-value \\
\hline $\begin{array}{l}\text { ICC } 16644 \times \text { JGK } \\
2\end{array}$ & 84 & $35.6 \pm 0.91$ & 126 & $31.6 \pm 0.75$ & $4.87 *$ & $<0.001$ \\
\hline $\begin{array}{l}\text { ICC } 16644 \times \mathrm{KAK} \\
2\end{array}$ & 78 & $33.0 \pm 0.84$ & 132 & $28.4 \pm 0.78$ & $4.51 *$ & $<0.001$ \\
\hline $\begin{array}{l}\text { ICC } \\
16644 \times \text { KRIPA }\end{array}$ & 82 & $38.1 \pm 0.78$ & 128 & $37.7 \pm 0.79$ & 0.44 & 0.33 \\
\hline $\begin{array}{l}\text { ICC } 16644 \times \text { ICC } \\
17109\end{array}$ & 86 & $39.4 \pm 0.82$ & 124 & $39.2 \pm 0.84$ & 0.45 & 0.11 \\
\hline Cross & $\begin{array}{l}\text { No. of } \\
\text { plants }\end{array}$ & $\begin{array}{l}\text { Days to first flower (mean } \pm \text { SE) of } \\
\text { small seeded plants of } F_{2}\end{array}$ & $\begin{array}{l}\text { No. of } \\
\text { plants }\end{array}$ & $\begin{array}{l}\text { Days to first flower } \\
\text { (mean } \pm \text { SE) of large seeded } \\
\text { plants }\end{array}$ & $t$-test & $P$-value \\
\hline $\begin{array}{l}\text { ICC } 16644 \times \text { JGK } \\
2\end{array}$ & 116 & $43.2 \pm 0.58$ & 94 & $37.2 \pm 0.57$ & $5.22 *$ & $<0.001$ \\
\hline $\begin{array}{l}\text { ICC } 16644 \times \text { KAK } \\
2\end{array}$ & 120 & $50.6 \pm 0.54$ & 90 & $43.2 \pm 0.64$ & $5.06^{*}$ & $<0.001$ \\
\hline $\begin{array}{l}\text { ICC } \\
16644 \times \text { KRIPA }\end{array}$ & 125 & $42.7 \pm 0.64$ & 85 & $41.7 \pm 0.68$ & 0.80 & 2.11 \\
\hline $\begin{array}{l}\text { ICC } 16644 \times \text { ICC } \\
17109\end{array}$ & 118 & $42.9 \pm 0.46$ & 82 & $41.8 \pm 0.51$ & 0.91 & 0.18 \\
\hline
\end{tabular}

*Significant difference at $P<0.001$

individuals in these crosses. In contrast, means of 100-seed weight of early and late flowering groups of $\mathrm{C}_{3}$ and $\mathrm{C}_{4}$ were at par, indicating late and early flowering group do not differ significantly in their mean 100-seed weight. Likewise, the mean of days to first flower for two groups of seed size i.e. small seeded group and large seeded group were compared. Significant differences for days to first flower in $\mathrm{C}_{1}$ and $\mathrm{C}_{2}$ were observed. In $\mathrm{C}_{1}$ there were a difference of $10.6 \mathrm{~g}$ (100-seed weight) and 6 days (days to first flower) between the groups. In $\mathrm{C}_{2}$, groups had difference of $12 \mathrm{~g}$ (100-seed weight) and 7.4 days (days to first flower). There were non-significant differences between the mean days to first flower of two groups for seed size in $\mathrm{C}_{3}$ and $\mathrm{C}_{4}$. These findings are in agreement with the findings from correlation studies.

Association among phenological traits

The data observed on $\mathrm{F}_{2}$ individuals were used to calculate correlation coefficients between flowering time and other phenological traits and, morphological and yield traits (Table 5). The association analysis revealed that phenological traits i.e. days to first flower, days to first pod formation and days to maturity were significantly positively correlated among each other in all the four crosses, suggesting early flower initiation leads to early pod setting which further leads to early maturity of genotype. Also, observations on flowering time can be recorded with more precision than on days to maturity (Gaur et al. 2015) particularly in long growing season environments thus flowering time can be used to select for early maturity. Gaur et al. (2015) suggested that, in general, the early flowering genotypes also mature early and the early flowering does not result in extending of reproductive period under residual soil moisture condition. However, in early flowering genotypes the duration of reproductive period may get extended due to indeterminate growth habit of chickpea (Subbarao et al. 1995). In the study, there was no supplementary irrigation or precipitation, these conditions might result early flowering lines to mature early, without extending the duration of reproductive phase. Several studies reported significant positive association among days to flowering and 


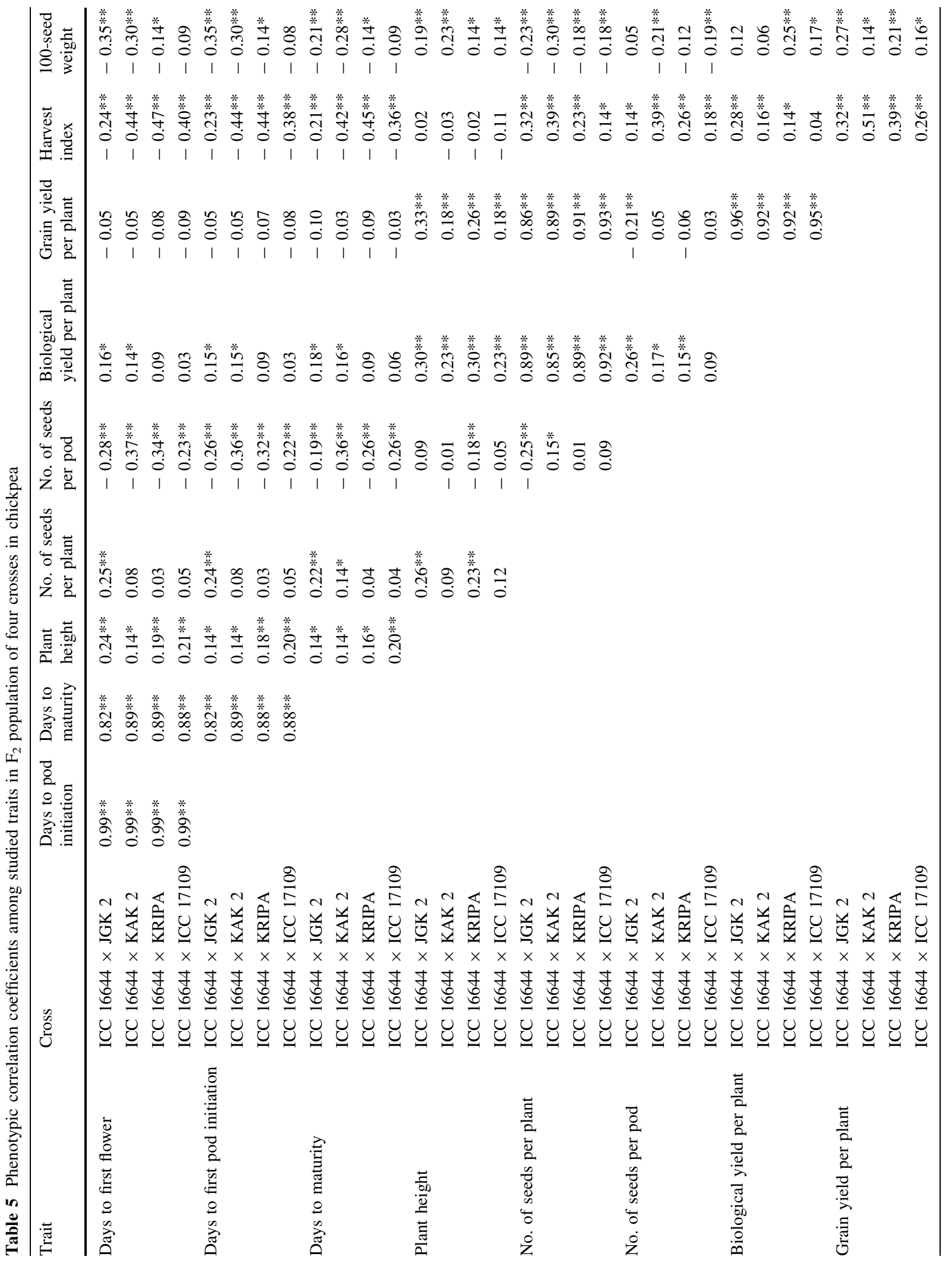




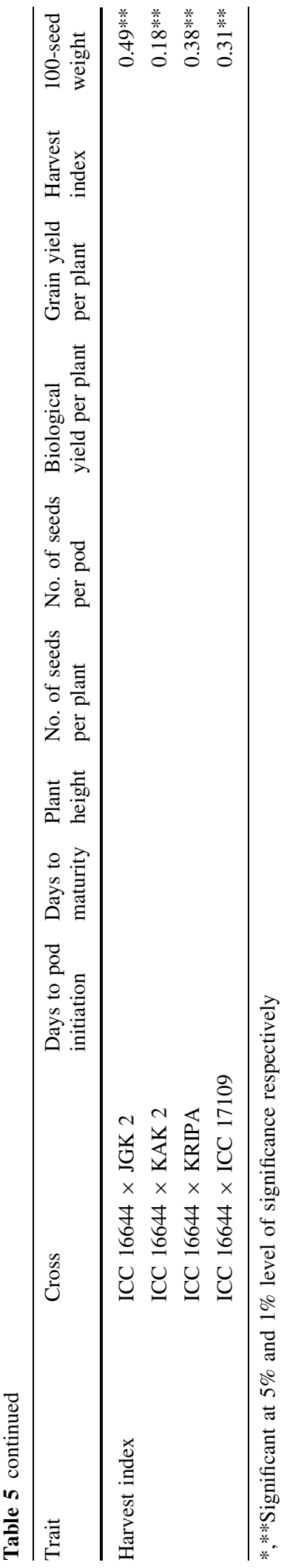

days to maturity in chickpea (Malik et al. 1988; Atta et al. 2008; Sidramappa et al. 2010; Naveed et al. 2012; Jivani et al. 2013; Monpara and Dhameliya 2013; Gaur et al. 2015).

Association of phenology with 100-seed weight

The efficiency of selection for phenology and seed size mainly depends upon the direction and magnitude of association between these traits. This is particularly important for kabuli chickpea, where seed size is an important yield component and a significant yield determinant. Days to first flower and days to first pod formation and days to maturity exhibited significant negative association with 100 -seed weight in $\mathrm{C}_{1}, \mathrm{C}_{2}$ and $\mathrm{C}_{3}$, while for $\mathrm{C}_{4}$ association was non-significant. While, Hovav et al. (2003) on the basis of association studies between time of flowering and 100-seed weight which were positively associated, suggested that in certain genetic backgrounds it might be difficult to breed early-flowering cultivars without compromising seed weight. Values of correlation coefficients were low revealing that early phenology might be a component of larger seed size. Seed size depends upon duration of reproductive phase, sink transfer, soil moistures condition during pod filling stage and gene involved. In earlier studies, either significant negative (Gaur et al. 2015) or no correlation (Ali et al. 2010; Jivani et al. 2013; Gaur et al. 2015) between days to flower initiation and 100-seed weight has been reported in chickpea. Thus, present and earlier studies show that in certain crosses there is scope of combining large seed size with earliness in chickpea. This is also supported by the fact that there are many large seeded kabuli type varieties with early maturity (Gaur et al. 2007).

Association of phenology with other traits

Phenology had no correlation with yield per se (seed yield per plant) in any of the crosses studied. These findings were corroborative with the findings of Arshad et al. (2004), Atta et al. (2008), Ali et al. (2010), Sidramappa et al. (2010), and Monpara and Dhameliya (2013). Thus there is no constraint in combining early phenology with higher grain yield in chickpea thereby allowing simultaneous selection for both traits. In general, it is difficult to improve both the yield as well as phenological traits simultaneously 
through selection. According to Or et al. (1999) genotypes with early flowering alleles, may have longer reproductive period which further enhance seed yield in chickpea by allowing formation of a relatively large numbers of pods and through longer grain filling duration. Phenological traits exhibited positive and significant correlation with plant height, indicating early flowering results into shorter plant height. If onset of reproductive phase i.e. flowering is early vegetative growth is reduced which further stop the growth of branches resulting in less plant height. Phenology showed either non-significant $\left(\mathrm{C}_{3}\right.$ or $\left.\mathrm{C}_{4}\right)$ or positive significant $\left(\mathrm{C}_{1}\right.$ and $\left.\mathrm{C}_{2}\right)$ correlation with biological yield per plant. Non-significant association of number of seeds per plant with phenology was observed in all the crosses except $\mathrm{C}_{1}$ where association was significant positive. These results indicate that early plants of these $F_{2}$ populations matured early and could not accumulate enough biomass (had less plant height and biomass), had lesser number of pods and seeds per plant than the late maturing plants. Results are in accordance with the findings of Gaur et al. (2015). Number of pods per plant was also studied, it had high significant positive $\left(\mathrm{C}_{1}-0.98 * *, \mathrm{C}_{2}-0.97 * *\right.$, $\left.\mathrm{C}_{3}-0.98 * *, \mathrm{C}_{4}-0.97 * *\right)$ association with number of seeds per plant so, only correlation coefficients of number of seeds per plant with other traits are included in the Table 5. Singh et al. (1990) reported that days to flowering and days to maturity contribute to seed yield mainly via biological yield and harvest index in chickpea. Thus, reducing the growth period after a threshold level may have a penalty on grain yield. Phenology showed significant negative association with harvest index in all the crosses. These results indicate that early genotypes are more efficient in their yield partitioning and accumulated biomass necessary to ensure optimum seed yield within shorter duration possibly through a higher crop growth rate. These results encourage combining earliness with high harvest index in these crosses. High harvest index and drought escape through early flowering and early maturity are considered as important attributes of adaptation in chickpea under drought stressed environments (Berger and Turner 2004).

\section{Association of yield and other traits}

Yield per plant was significantly positively associated with plant height, number of seeds per plant, number of pods per plant, biological yield per plant, 100-seed weight and harvest index and hence could be considered as factors for seed yield improvement. Results indicate that for higher yield, selection of genotypes with taller plant height, higher harvest index, a greater number of pods, more biological yield per plant and seeds per plant with larger seed size traits would be beneficial in these crosses. Generally, biological yield and harvest index are accepted as the most important traits for improving grain yield. Such positive interrelationship between these attributes had also been reported in chickpea. (Arshad et al. 2004; Vaghela et al. 2009; Jivani et al. 2013). 100-seed weight had positive correlation with grain yield per plant. Mathur and Mathur (1996) and Ali et al. (2010) had similar results, while Lal et al. (1993) reported a negative correlation between seed yield and 100-seed weight. Number of pods per plant, number of seeds per plant and biological yield per plant were highly interrelated among each other. These results get support with the findings of Ali et al. (2010). Number of seeds per pod had significant negative association $\left(\mathrm{C}_{2}\right.$ and $\left.\mathrm{C}_{4}\right)$ or no association with 100-seed weight indicating either a pod has a greater number of smaller seeds or a lesser number of larger seeds. In the study 100-seed weight was positively associated with harvest index and plant height but, 100-seed weight had significant negative association with number of pods and seeds per plant indicating plant with larger seed size had less pods and seeds and vice versa. So, variety with higher yield will have either a greater number of pods and seeds or will have larger seeds. Simultaneous selection for both a greater number of pods and seeds and larger seed size may not be possible. Some difficulties might be encountered in breeding larger seed cultivar without compromising number of pods and seeds per plant.

\section{Conclusions}

Early phenology is an important trait for adaptation of chickpea to different environments. In kabuli chickpea, the seed size is an important trait for marketing. The genetic control of seed size in kabuli chickpea is under two major genes exhibiting complementary epistasis and small size is dominant over large. Furthermore, two major genes with duplicate recessive epistasis control flowering time in kabuli chickpea where lateness is dominant over earliness. The 
results of association studies suggest that phenology had significant negative association with seed size in some crosses and no association in other crosses. Thus, in certain genetic background, it would be possible to breed early flowering cultivars with large seed size by allowing simultaneous selection for both the traits. These findings will be useful to plant breeders in designing strategies to develop early maturing varieties of chickpea with large seed size.

The early maturing parent ICC 16641 used in this study has been reported to carry the early flowering gene efl-4 (Gaur et al. 2015). Studies on allelic relationships of efl-4 with other early flowering genes, efl-1 (present in ICCV 2), efl-2 (present in ICC 5810) and efl-3 (present in BGD 132) indicated that these early flowering genes are non-allelic (Gaur et al. 2015). Availability of four different early flowering genes with similar effects provide options for choosing a specific early flowering gene based on the desired background and linkage relationships of the flowering time genes with other traits (Gaur et al. 2015). Major QTLs corresponding to flowering time genes efl-1, efl3 and efl-4 have been mapped on CaLG04, CaLG08 and CaLG06, respectively (Mallikarjuna et al. 2017). Thus, markers identified linked to these QTLs can be used in marker-assisted breeding for developing early maturing varieties and combining early maturity trait with other desired traits, such as seed size.

Acknowledgements CGIAR (Consultative Group on International Agricultural Research) Research Program on Grain Legumes for financial support.

\section{References}

Ali Q, Ahsan M, Farooq J, Saleem M (2010) Genetic variability and trait association in chickpea (Cicer arietinum L.). Electron J Plant Breed 1:328-333

Anbessa Y, Warkentin T, Vandenberg A, Ball R (2006) Inheritance of time to flowering in chickpea in a short-season temperate environments. J Hered 97:55-61

Argikar GP (1956) Some qualitative and quantitative observation on the genetic improvement of green seeded strain of Cicer arietinum L. Indian J Genet Plant Breed 16:52-56

Arshad M, Bakshi A, Ghafoor A (2004) Path coefficient analysis in Chickpea (Cicer arietinum L.) under rainfed conditions. Pak J Bot 36:75-81

Atta BM, Haq MA, Shah TM (2008) Variation and inter-relationships of quantitative traits in chickpea (Cicer arietinum L.). Pak J Bot 40:637-647

Balasubrahmanyan R (1950) The association of size and colour in gram (Cicer arietinum L.). Current Sci 19:246-247
Berger JD, Turner NC (2004) Genotype by environment studies across Australia reveal the importance of phenology for chickpea (Cicer arietinum L.) improvement. Aust J Agric Res 55:1071-1084

Berger JD, Ali M, Basu PS et al (2006) Genotype by environment studies demonstrate the critical role of phenology in adaptation of chickpea (Cicer arietinum L.) to high and low yielding environments of India. Field Crops Res 98:230-244

Bernard RL (1971) Two genes for time of flowering and maturity in soybeans. Crop Sci 11:242-244

Bonato ER, Vello NA (1999) E6, a dominant gene conditioning early flowering and maturity in soybeans. Genet Mol Biol 22:229-232

Bonfil DJ, Pinthus MJ (1995) Respcnse of chickpea to nitrogen and the comparison of the factors affecting chickpea seed yield to those affecting wheat grain yield. Exp Agric 31:39-47

Buzzell RI (1971) Inheritance of a soybean flowering response to fluorescent-daylength conditions. Can J Genet Cytol 13:703-707

Buzzell RI, Voldeng HD (1980) Research Notes: inheritance of insensitivity to long daylength. Soyb Genet News1 7:26-29

Cober ER, Voldeng HD (2001) A new soybean maturity and photoperiod-sensitivity locus linked to E1 and T. Crop Sci 41:698-701

Coyne DP, Mattson RH (1964) Inheritance of time of flowering and length of blooming period in Phaseolus vulgaris L. J Am Soc Hortic Sci 85:366-373

Craufurd PQ, Soko HS, Jones JK, Summerfield RJ (2001) Inheritance of duration from sowing to first flowering in pigeonpea. Euphytica 119:323-333

Dahiya BS, Solanki IS, Kumar R (1985) Germination rate and its genetics in chickpea. Int Chickpea Newsl 13:6-8

Ellis RH, Lawn RJ, Summerfield RJ et al (1994) Towards the reliable prediction of time to flowering in six annual crops: V. Chickpea (Cicer arietinum). Exp Agric 30:271-282

FAOSTAT (2017) http://faostat.fao.org/site. Accessed June 2019

Gaur PM, Gowda CLL, Knights EJ et al (2007) Breeding achievements. In: Yadav SS, Redden B, Chen W, Sharma $\mathrm{B}$ (eds) Chickpea breeding and management. CAB International, Wallingford, pp 391-416

Gaur PM, Krishnamurthy L, Kashiwagi J (2008a) Improving drought-avoidance root traits in chickpea (Cicer arietinum L.): current status of research at ICRISAT. Plant Prod Sci 11:3-11

Gaur PM, Kumar J, Gowda CLL et al (2008b) Breeding chickpea for early phenology: perspectives, progress and prospects. In: Kharkwal MC (ed) Food legumes for nutritional security and sustainable agriculture, vol 2. Indian Society of Genetics and Plant Breeding, New Delhi, pp 39-48

Gaur PM, Tripathi S, Gowda CLL et al (2010) Chickpea seed production manual. International Crops Research Institute for the Semi-Arid Tropics, Patancheru

Gaur PM, Samineni S, Tripathi S, Varshney RK, Gowda CLL (2015) Allelic relationships of flowering time genes in chickpea. Euphytica 203:295-308 
Gaur PM, Samineni S, Thudi M et al (2018) Integrated breeding approaches for improving drought and heat adaptation in chickpea (Cicer arietinum L.). Plant Breed 00:1-12

Ghatge RD (1993) Inheritance of seed size in chickpea (Cicer arietinum L.). J Soils Crops 3:56-59

Graham J, Matassa V, Panozzo J, Starick N (2001) Genotype and environment interaction for whole grain colour in chickpea. In: 4th European conference on grain legumes, pp 372-373

Gumber RK, Singh S (1996) Genetics of flowering time in chickpea: a preliminary report. Crop Improv-India 23:295-296

Hegde VS (2010) Genetics of flowering time in chickpea in a semi-arid environment. Plant Breed 129:683-687

Hossain S, Ford R, Mcneil D, Pittock C, Panozzo JF (2010) Inheritance of seed size in chickpea (Cicer arietinum L.) and identification of QTL based on 100-seed weight and seed size index. Aust J Crop Sci 4:126-135

Hovav R, Upadhyaya KC, Beharav A, Abbo S (2003) Major flowering time gene and polygene effects on chickpea seed weight. Plant Breed 122:539-541

Jivani JV, Mehta DR, Vaddoria MA, Raval L (2013) Correlation and path coefficient analysis in Chickpea (Cicer arietinum L.). Electron J Plant Breed 4:1167-1170

Khanna-Chopra R, Sinha SK (1987) Chickpea: physiological aspects of growth and yield. In: Saxena MC, Singh KB (eds) The chickpea. CAB International, Wallingford, pp 163-189

Koebner R, Saxena KB, Byth DE, Wallis ES (1991) Inheritance of flowering time in pigeonpea. Int Chickpea Pigeonpea Newsl 1:12

Kumar J, Abbo S (2001) Genetics of flowering time in chickpea and its breeding on productivity in semiarid environments. Adv Agron 72:107-137

Kumar S, Singh O (1995) Inheritance of seed size in chickpea. J Genet Breed 49:99-104

Kumar J, van Rheenen HA (2000) A major gene for time of flowering in chickpea. J Hered 91:67-68

Kumhar BL, Singh D, Bhanushally TB, Koli NR (2013) Gene effects for yield and yield components in chickpea (Cicer arietinum L.) under irrigated and rainfed conditions. J Agric Sci 5:1-13

Lal R, Dhangu BK, Gupta VP (1993) Variability, correlation and path analysis in gram. Haryana Agric Univ J Res $23: 1-3$

Lemontey C, Mousset-Declas C, Munier-Jolain N, Boutin J (2000) Maternal genotype influences pea seed size by controlling both mitotic activity during early embryogenesis and final endoreduplication level/cotyledon cell size in mature seed. J Exp Bot 51:167-175

Malhotra RS, Bejiga G, Singh KB (1997) Inheritance of seed size in chickpea. J Genet Breed 51:45-50

Malik BA, Khan IA, Malik MR (1988) Genetic variability and correlations among metric traits in chickpea. Pak J Agric Res 9:352-354

Mallikarjuna BP, Samineni S, Thudi M, Sajja SB, Khan AW, Patil A, Viswanatha KP, Varshney RK, Gaur PM (2017) Molecular mapping of flowering time major genes and QTLs in chickpea (Cicer arietinum L.). Front Plant Sci. https://doi.org/10.3389/fpls.2017.01140
Mathur R, Mathur ML (1996) Estimation of genetic parameters and interrelationship of quantitative traits in chickpea. Madras Agric J 83:9-11

McBlain B, Bernard RL (1987) A new gene affecting the time of flowering and maturity in soybean. J Hered 78:160-162

Monpara BA, Dhameliya HR (2013) Genetic behaviour of earliness related traits and seed yield in chickpea (Cicer arietinum L.). Pak J Biol Sci 16:955-959

Murfet IC (1985) Pisum sativum L. In: Halevy AH (ed) Handbook of flowering. CRC Press, Boca Raton, pp 97-126

Narayanan A, Saxena NP, Sheldrake AR (1981) Varietal differences in seed size and seedling growth of pigeonpea and chickpea. Indian J Agric Sci 51:389-393

Naveed MT, Ali Q, Ahsan M, Hussain B (2012) Correlation and path coefficient analysis for various quantitative traits in chickpea (Cicer arietinum L.). IJAVMS 6:97-106

Niknejad M, Khosh-khui M, Ghorashy SR (1971) Inheritance of seed size in chickpeas (Cicer arietinum L.). Crop Sci 11:768-769

Or E, Hovav R, Abbo S (1999) A major gene for flowering time in chickpea. Crop Sci 39:315-322

Patil JA, D'Cruze R (1964) Inheritance of seed size in gram (Cicer arietinum). Poona Agric Coll Mag 54:21-22

Ray JD, Hinson K, Manjono JEB, Malo MF (1995) Genetic control of a long-juvenile trait in soybean. Crop Sci 35:1001-1006

Roberts EH, Hadley P, Summerfield RJ (1985) Effects of temperature and photoperiod on flowering in chickpeas (Cicer arietinum L.). Ann Bot 55:881-892

Sarker A, Erskine W, Sharma B, Tyagi MC (1999) Inheritance and linkage relationships of days to flower and morphological loci in lentil (Lens culinaris Medikus subsp. Culinaris). J Hered 90:270-275

Saxena KB, Sharma D (1990) Pigeonpea: genetics. In: Nene YL, Hall SD, Sheila VK (eds) The pegionpea. CAB International, Wallingford, pp 137-157

Sidramappa, Patil SA, Salimath PM (2010) Association of phenological traits with productivity and its components in chickpea (Cicer arietinum L.). Legume Res 33:201-205

Singh O, Paroda RS (1986) Association analysis of grain yield and its componants in chickpea following hybridization and a combination of hybridization and mutagenesis. J Agric Sci 56:139-141

Singh KB, Bejiga G, Malhotra RS (1990) Associations of some characters with seed yield in chickpea collections. Euphytica 49:83-88

Smithson JB, Thompson JA, Summerfield RJ (1985) Chickpea (Cicer arietinum L.) In: Summerfield RJ, Roberts EH (eds) Grain legume crops. Collins, London, UK. pp 312-390

Snape JW, Butterworth K, Whitechruch E, Worland AJ (2001) Waiting for fine times: genetics of flowering time in wheat. Euphytica 119:185-190

Subbarao GV, Johansen C, Slinkard AE, Rao RC, Saxena NP, Chauhan YS (1995) Strategies for improving drought resistance in grain legumes. Crit Rev Plant Sci 14:469-523

Summerfield RJ, Roberts EH (1988) Photothermal regulation of flowering in pea, lentil, faba bean and chickpea. In: Summerfield RJ (ed) World crops: cool season food legumes. Kluwer Academic Publishers, Dordecht, pp 911-922 
Upadhyaya HD, Kumar S, Gowda C, Singh S (2006) Two major genes for seed size in chickpea (Cicer arietinum L.). Euphytica 147:311-315

Upadhyaya HD, Sharma S, Gowda CLL (2011) Major genes with additive effects for seed size in kabuli chickpea (Cicer arietinum L.). J Genet 90:479-482

Vaghela MD, Poshiya VK, Savaliya JJ et al (2009) Studies on character association and path analysis for seed yield and its components in chickpea (Cicer arietinum L.). Legume Res 32:245-249
Warkentin T, Vandenberg A, Banniza S et al (2003) Breeding chickpea for improved Ascochyta blight resistance and early maturity in western Canada. In: Sharma RN, Yasin M, Swami SL, Khan MA, William AJ (eds) Proceedings of international chickpea conference, Indira Gandhi Agricultural University, 20-22 January Raipur, India, pp 1-4

Publisher's Note Springer Nature remains neutral with regard to jurisdictional claims in published maps and institutional affiliations. 